\title{
Giant Primary Mediastinal Leiomyoma Diagnosed with EBUS-TBNA: A Case Report
}

\author{
EBUS TBİA ile Tanı Konulan Dev Primer Mediastinal Leiomyom: Olgu Sunumu
}

Serap Duru' ${ }^{1}$ Emine Bahar Kurt' ${ }^{1}$, Tuğba Taşkın Türkmenoğlu², Kubilay Inan ${ }^{3}$

\section{Abstract}

Mediastinal leiomyomas are usually of esophageal origin, among which primary mediastinal leiomyomas are extremely rare. The current approach to the treatment of giant primary mediastinal leiomyoma involves the removal of the mass by thoracic surgery. We present here a case with leiomyoma of the posterior mediastinum that was compressing the trachea, and that was diagnosed via EBUS TBNA.

Key words: EBUS-TBNA, leiomyoma, mediastinal mass.

\section{Özet}

Mediyastinal leiomyomlar genellikle özefagus kökenlidir. Primer mediastinal leiomyom ise oldukça nadir görülmektedir. Dev primer mediyastinal leiomyomun tedavisi torasik cerrahi ile kitlenin çıkarılmasıdır. Bu yazıda EBUS TBIA ile tanı konulan ve trakeaya bası yapan arka mediastende leiomyomu olan olguyu sunduk.

Anahtar Sözcükler: EBUS-TBIA, leiomyom, mediastinal kitle.
'Department of Thoracic Diseases, HSU Dışkapı Yıldırım Beyazı HARC, Ankara, Turkey

${ }^{2}$ Department of Pathology, HSU Dışkapı Yıldıım Beyazı HARC, Ankara, Turkey

${ }^{3}$ Department of Thoracic Surgery, HSU Dışkapı Yıldırım Beyazıt HARC, Ankara, Turkey
'SBÜ Dışkapı Yıldırım Beyazıt SUAM, Göğüs Hastalıkları Kliniği, Ankara

${ }^{2}$ SBÜ Dışkapı Yıldırım Beyazı SUAM, Patoloji Kliniği, Ankara ${ }^{3}$ SBÜ Dışkapı Yıldırım Beyazı SUAM, Göğüs cerrahisi Kliniği, Ankara

Submitted (Başvuru tarihi): 15.05.2021 Accepted (Kabul tarihi): 14.07.2021

Correspondence (iletişim): Serap Duru, Department of Thoracic Diseases, HSU Dışkapı Yıldırım Beyazıt HARC, Ankara, Turkey

e-mail: akcalis@hotmail.com 
Leiomyomas generally occur in the uterus, urinary tract or gastrointestinal tract. Primary Mediastinal Leiomyomas (PML) can rarely be seen in the intrathoracic area, developing from the smooth muscle $(1,2)$. We describe here a rare case of a giant PML, diagnosed histopathologically by Endobronchial Ultrasonography guided transbronchial needle aspiration (EBUS-TBNA).

\section{CASE}

A 42-year-old male presented to our chest disease clinic with progressive chest pain and shortness of breath that had been ongoing for 6 months. The patient had no gastrointestinal tract problem symptoms, and clinical examination and laboratory tests were normal. A fixed airflow obstruction was detected in a respiratory function test.

Figure 1 shows an irregularity at the heart's borders with the lung, and linear atelectasis in the left hemidiaphragm on a posteroanterior chest radiograph. The computed tomography of lung shows a $31 \times 45 \times 32 \mathrm{~mm}$ soft tissue mass in the subcarinal area (Figure 2). A hypermetabolic appearance [maximum standardized uptake value (SUVmax): 8.9] was noted on positron emission tomography (PET-CT). Endobronchial USG revealed a large a mass (49 $\mathrm{mm} \times 29 \mathrm{~mm}$ ) compressing the trachea (Figure 3), samples of which were obtained for histopathological examination through EBUS-TBNA. No associated mediastinal lymph node enlargement was detected on PET-CT. The patient was consulted with thoracic surgery and taken into operation. The mass, which started from the lower end of the esophagus and filled the subcarinal area, was removed surgically. It had no connection with esophagus or the great vessels, and all retrieved lymph nodes were clear. A cytological examination of the mass and the spindle cells revealed by the EBUS-TBNA had no cytological atypia and no evident mitotic activity. The cells showed diffuse and strong staining for Desmin, SMA, Caldesmon, while being negative for CD117, DOG-1, BCL-2, CD34, and S100 on immunohistochemistry, consistent with a spindle cell mesenchymal neoplasia, and a smooth muscle-derived mesenchymal tumor (leiomyoma). Photomicrographs of smears showing cellular tissue fragments composed of spindle cells $(a, b)$ and cell block material (c) (a May Grümwald Giemsa , b PAP, c Hematoxylin-Eosin $\mathrm{x}$ 100) are shown in Figure 4. In immunohistochemical studies of cell block-section, positivity is seen for Desmin (a), smooth muscle actin (b), caldesmon and (c), negativity for DOG-1 antibodies (a,b,c,d x100) in Figure 5. Low-power magnification revealed a well- circumscribed tumor composed of spindle cells (a), and at a high power magnification, intersecting fascicles of bland-looking spindle cells can easily be identified ( $a \times 40$ b x100, both Hematoxylin-Eosin) in Figure 6. It was thus evaluated as PML by a pathologist and thoracic surgeon. Six month and first-year controls were normal, with no recurrence detected on chest $X$-ray or computed tomography. The rarity of the condition, and the selected diagnosis and treatment steps are discussed and offered together with current literature.

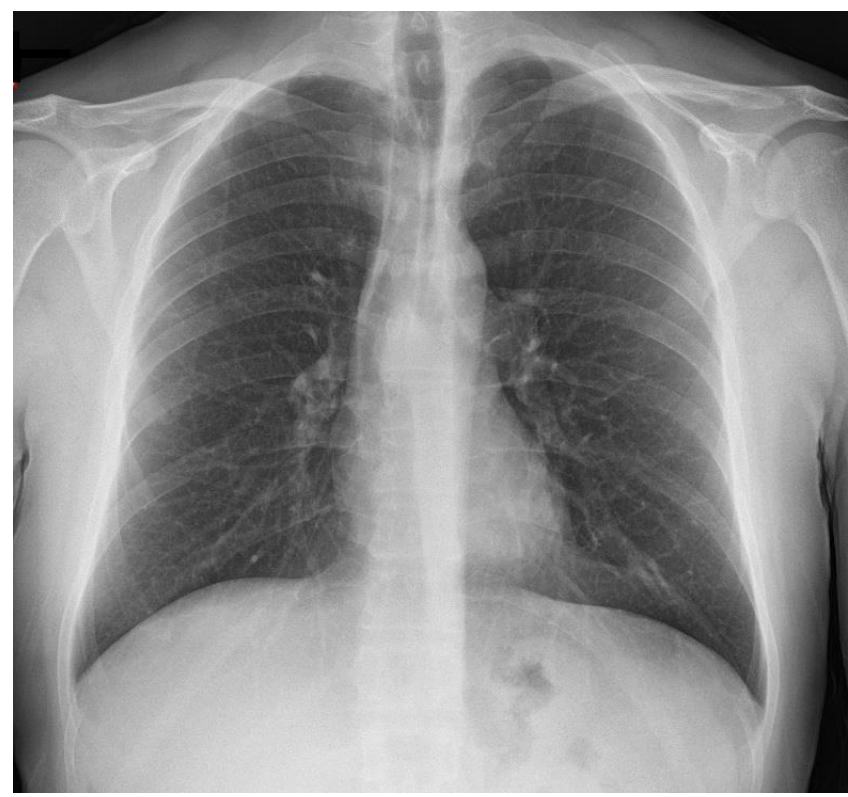

Figure 1: Chest radiograph image showing an increase in density in the left lower zone
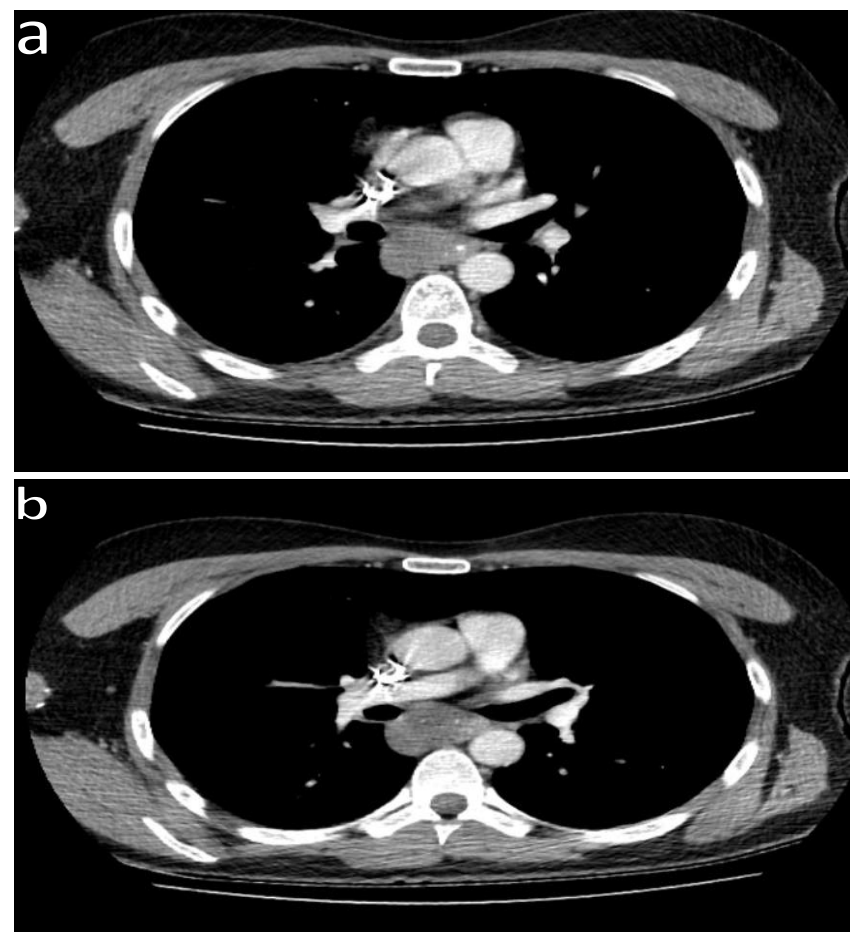

Figure 2: Computed tomography image showing a mass in the subcarinal area 


\section{DISCUSSION}

Leiomyomas are generally localized in the esophagus, and account for $10 \%$ of all gastrointestinal leiomyoma in the mediastinum (3). Rare benign tumors of smooth muscle PML usually occur in women between the 2 nd and 5 th decades. Although the pathogenesis of leiomyoma is obscure, estrogen and traumatic theories have been suggested $(1,4,5)$. These tumors account for $1-6 \%$ of all mediastinal tumors, and are known to be slow-growing tumors with low malignancy potential. The most common symptoms are dysphagia, non-specific chest pain and retrosternal pain, and less commonly regurgitation, epigastric tenderness, shortness of breath and weight loss $(3,6,7)$. The symptoms and age of our case were consistent with literature. Chest radiography is not sensitive or specific enough for the diagnosis of PML $(8,9)$, but with the enlargement of the mass it may become visible on chest radiograph. Computed tomography of the lung and PET-CT has an estimated sensitivity of 91-95\% for the evaluation of PML. In our case, an increase in density was noted in the left lower zone causing an irregularity at the heart borders identified on a chest radiography, and the mass was diagnosed through a computed tomography of lung and immunohistochemical staining, and was identified as a posterior mediastinal mass. The patient had no other symptoms, such as dysphagia, epigastric tenderness, fever or hematemesis. Very few cases of PML have previously been reported, and diagnosis via EBUS-TBNA is also extremely rare $(5,10)$. EBUS-TBNA is a minimally invasive approach to the examination and staging of mediastinal lesions $(11,12)$. The patient was referred to our clinic and was assessed with EBUS-TBNA. A gastrointestinal tract endoscopy was not preferred primarily. The surgical removal of the tumor is the classic treatment recommended for primary mediastinal leiomyoma. A review of literature revealed PMLs to be usually completely resectable, and to generally provide a cure (13). In the present case, thoracic surgery was consulted, and the tumor filling the subcarinal area was removed by thoracic surgery. No recurrence was observed in the cases in literature, and there had been no recurrence three years after the operation in the present case.

In the present case, a benign spindle-cell neoplasm was diagnosed via EBUS-TBNA before surgery. Given the age of the patient, esophageal leiomyoma or lung cancer were considered during differential diagnosis. Although rare, PML should be considered in the differential diagnosis of an unexplained mass in the mediastinum.

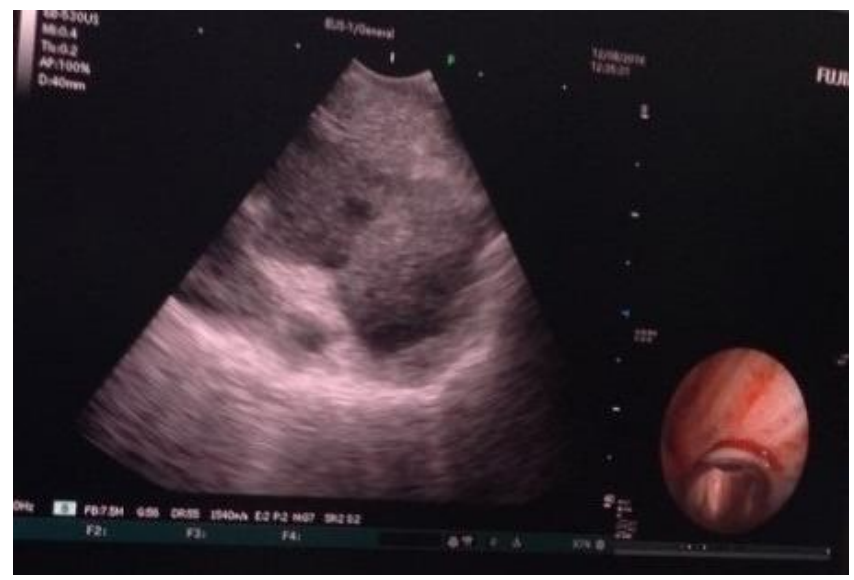

Figure 3: Endobronchial USG showing a hypoechoic heterogeneous mass in the subcarinal area

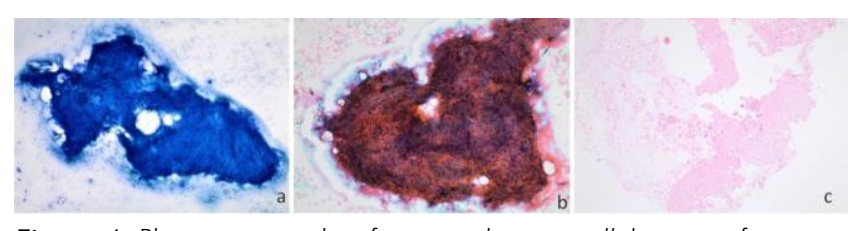

Figure 4: Photomicrographs of smears showing cellular tissue fragments composed of spindle cells $(a, b)$ and cell block material (c) (a May Grümwald Giemsa, b PAP, c Hematoxylin-Eosin X100)

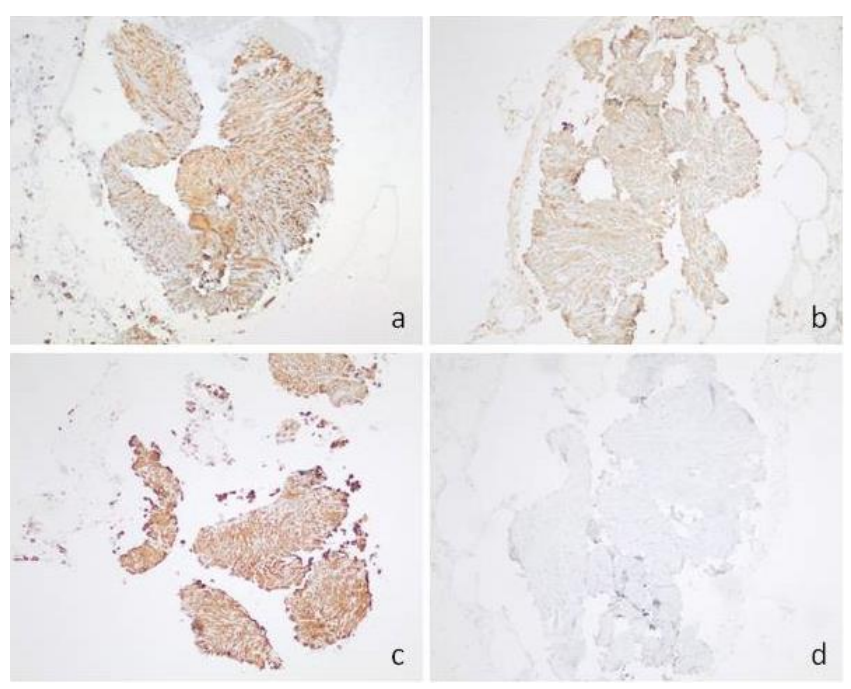

Figure 5: In immunohistochemical studies of cell block sections, positivity is seen for desmin (a), smooth muscle actin (b) and caldesmon (c), and negativity for DOG-1 antibodies (a,b,c,d X100)

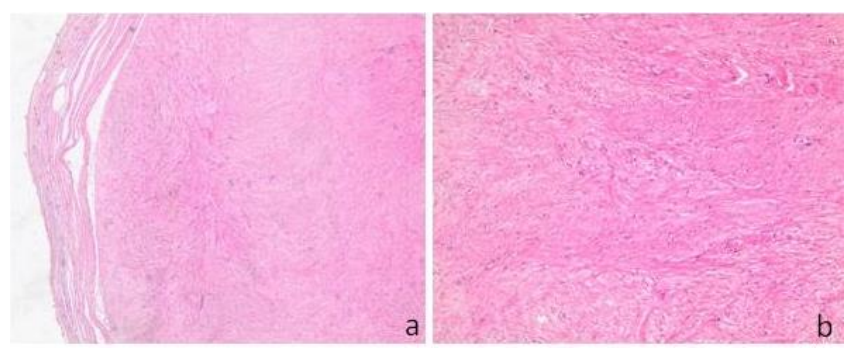

Figure 6: At low power magnification, a well-circumscribed tumor composed of spindle cells (a), and at high power magnification, intersecting fascicles of bland-looking spindle cells can be easily identified (a X40, b X100 both Hematoxylin-Eosin) 


\section{CONCLUSION}

Primary Mediastinal Leiomyoma progress slowly and have a favorable prognosis. Endobronchial ultrasonography is an effective and reliable approach to the sampling of lesions adjacent to the trachea and bronchi. We believe that given the rare occurrence of PML, the use of EBUS TBNA for diagnosis may be of benefit to clinicians.

\section{CONFLICTS OF INTEREST}

None declared.

\section{AUTHOR CONTRIBUTIONS}

Concept - S.D., E.B.K., T.T.T., K.I.; Planning and Design - S.D., E.B.K., T.T.T., K.I.; Supervision - S.D., E.B.K., T.T.T., K.I.; Funding - S.D., K.I.; Materials - S.D., T.T.T.; Data Collection and/or Processing - S.D., E.B.K., T.T.T.; Analysis and/or Interpretation - S.D., T.T.T., K.I.; Literature Review - S.D., K.I.; Writing - S.D., E.B.K.; Critical Review - S.D., T.T.T.

\section{YAZAR KATKILARI}

Fikir - S.D., E.B.K., T.T.T., K.I.; Tasarım ve Dizayn - S.D., E.B.K., T.T.T., K.I.; Denetleme - S.D., E.B.K., T.T.T., K.I.; Kaynaklar - S.D., K.I.; Malzemeler - S.D., T.T.T.; Veri Toplama ve/veya İşleme - S.D., E.B.K., T.T.T.; Analiz ve/veya Yorum - S.D., T.T.T., K.I.; Literatür Taraması S.D., K.I.; Yazıyı Yazan - S.D., E.B.K.; Eleştirel İnceleme S.D., T.T.T.

\section{REFERENCES}

1. Li C, Lin F, Pu Q, Liu L. Primary mediastinal leiomyoma: a rare case report and literature review. J Thorac Dis. 2018; 10:E1 16-9. [CrossRef]

2. Haratake N, Shoji F, Kozuma Y, Okamoto T, Maehara Y. Giant leiomyoma arising from the mediastinal pleura: a case report. Ann Thorac Cardiovasc Surg 2017; 23:1536. [CrossRef]

3. Snène $H$, Blibech $H$, Mehiri $N$, Ben Salah $N$, Louzir B. Esophageal leiomyomas presenting as a mediastinal mass. Tunis Med 2020; 98:475-9.
4. Matsuoka H, Nishio W, Sakamoto T, Harada H, Sashikata T, Tsubota N. Mediastinal Angioleiomyoma. Ann Thorac Surg 2002; 73:1653-4. [CrossRef]

5. Shaffer K, Pugatch RD, Sugarbaker DJ. Primary mediastinal leiomyoma. Ann Thorac Surg 1990; 50:301-2. [CrossRef]

6. Thakut G, Murchite SA, Kulkarni RM, Gaikwad W. Leiomyoma of esophagus-A case report. Int J Surg Case Rep 2020: 76:285-7. [CrossRef]

7. Ouadnouni Y, Achir A, Bekarsabein S, Bouchikh M, Smahi M, Msougar $Y$, et al. Primary mediastinal leiomyoma: a case report. Cases J. 2009; 2:8555. [CrossRef]

8. Ha C, Regan J, Çetindag IB, Ali A, Mellinger JD. Benign esophageal tumors. Surg Clin N Am 2015; 95:491-514. [CrossRef]

9. Storey CF, Adams WC Jr. Leiomyoma of the esophagus: a report of four cases and review of the surgical literature. Am J Surg 1956; 9: 3-23. [CrossRef]

10. Uno A, Sakurai M, Onuma K, Yamane Y, Kurita K, Hayashi $\mathrm{l}$, et al. A case of a giant mediastinal leiomyoma with long-term survival. Tohoku J Exp Med 1988; 156:1 6. [CrossRef]

11. Darwiche K, Özkan F, Wolters C, Eisenmann S. Endobronchial ultrasound (EBUS) - an update 2017. Pneumologie 2017; 71:798-812. [CrossRef]

12. Stern JB, Wyplosz B, Girard P, Validire P, Escaut L, Caliandro R. Endobronchial ultrasonography (EBUS) for the internist. Rev Med Interne 2016; 37:759-65. [CrossRef]

13. Baldó X, Sureda C, Gimferrer JM, Belda J. Primary mediastinal leiomyoma: an angiographic study and embolisation of the feeding vessels to improve the surgical approach. Eur J Cardiothorac Surg 1997; 11:574-6. [CrossRef] 